\title{
UNJUK RASA DI KAWASAN TERBATAS BANDAR UDARA SEBAGAI PELANGGARAN HUKUM DAN ANCAMAN KESELAMATAN PENERBANGAN \\ SERTA PENCEMARAN CITRA BANDAR UDARA INTERNASIONAL DI INDONESIA \\ Mochammad Fatchoelqorib,SH.,MM
}

\begin{abstract}
Airport, especialy International Airport has many dimension in perspective of view. It is a strategic place for the development of economic of the country, as well as window for the image of the country. Security and safety aspect are mandatory for aviation operations, as well as airport operations. Many regulations regarding airport security and safety already developed and forced, but in some places the compliance is still low. There were some actions toke place in the restricted area at Susilo Airport of Sintang City and Supadio International Airport of Pontianak city in Western Kalimantan, also at Sam Ratulangi Airport of Manado city in North Sulawesi. Even though there were no serious incidense regarding safety but there were already threatening for security and safety in the restricted area of those airports.

Rather than security and safety aspect, those activity also can jeoperdice the image of compliance to the rules and regulations especialy for those airport operated internationaly. .
\end{abstract}

\section{FAKTA DARI PERISTIWA}

Sejumlah peristiwa masuknya orang-orang yang tidak mempunyai keabsahan di area terbatas bandara, telah terjadi beberapa kali di beberapa bandara di Indonesia. Peristiwa-peristiwa tersebut terekam dalam berita di masmedia seperti terkutip berikut ini:

Yang pertama terjadi di Bandara Susilo Kabupaten Sintang Kalimantan Barat.

TEMPO.CO, Pontianak - Sejumlah orang yang mengatasnamakan Dewan Adat Dayak (DAD) Kabupaten Sintang menolak kedatangan Wakil Sekretaris Jenderal Majelis Ulama Indonesia Tengku Zulkarnain sesaat setelah dia mendarat di Bandara Susilo, Kabupaten Sintang, Kalimantan Barat, Kamis, 12 Januari 2016

Karena aksi tersebut, pada pukul 10.30 WIB, Tengku Zulkarnain beserta rombongan tidak jadi turun dari pesawat dan langsung meninggalkan Sintang menggunakan pesawat Garuda Indonesia menuju Pontianak.(penebalan huruf oleh penulis) 
Peristiwa berikutnya terjadi di Bandara Supadio Pontianak, juga di Kalimantan Barat.

PKSPUYENGAN.COM - warga Dayak Usir Ketua FPI Sobri Lubis Dari Bandara Supadio Pontianak. Penolakan rombongan DPP FPI oleh masyarakat Dayak Pontianak Kalbar dan aparat keamanan di Bandara Supadio Pontianak Kalbar berlangsung cukup dramatis. Ketua DPP FPI Sobri Lubis dan Hidayat Qodri Batanghari beserta rombongan tiba di bandara Internasional Supadio Pontianak, Kalbar, menggunakan pesawat komersial Lion Air JT -716, pada Jumat (5/5/2017) sekitar pukul 19.50 WIB. Tapi tidak sampai 30 menit, Ketua DPP FPI beserta rombongan kembali pulang menuju Jakarta pada pukul 20.02 Wib dengan menggunakan pesawat Citylink $Q G-867$.

Sedangkan rombongan yang akan menyambut ketua FPI itu diusir Polisi. Kapolres Pontianak yang memimpin langsung aksi tersebut membentak bentak dan mengancam akan menangkap anggota FPI jika membuat kerusuhan.

Peristiwa yang lain pada tahun yang sama terjadi di Bandara Sam Ratulangi Manado, Sulawesi Utara.

TEMPO.CO, Jakarta - Massa dari berbagai penjuru Sulawesi Utara memblokir Bandar Udara Sam Ratulangi di Manado, Sabtu, 13 Mei 2017, dari pagi hingga siang. Mereka menolak kedatangan Wakil Ketua Dewan Perwakilan Rakyat dan politikus Partai Keadilan Sejahtera, Fahri Hamzah. MANADO, KOMPAS.com - Sekitar seribuan massa mendobrak pintu keluar penumpang Bandara Sam Ratulangi Manado, Sabtu (13/5/2017). Desakan massa yang membuat kerepotan petugas keamanan itu mengakibatkan pintu keluar yang terbuat dari kaca pecah dan ambruk. ............... Massa yang juga disertai dengan penari Kabasaran yang membawa parang panjang merengsek ke bagian pengambilan bagasi. Sambil berteriak-teriak mereka menuju ke tempat parkir pesawat.

Liputan6.com, Manado - Ribuan warga dari berbagai ormas di Sulawesi Utara sejak pukul 08.00 Wita mulai menduduki Bandar Udara Sam Ratulangi, Manado, Sabtu (13/5/2017). Aksi massa ini untuk mengadang kedatangan Wakil Ketua DPR, Fahri Hamzah, bersama rombongan Aksi ribuan massa yang menolak kehadiran Wakil Ketua DPR Fahri Hamzah di Bandara Udara Sam Ratulangi, Manado masih berlanjut. Mendengar informasi bahwa Fahri berada di gedung VVIP, demonstran memaksa masuk dengan menerobos 
gerbang. Aksi dorong mendorong dengan aparat keamanan tak terhindarkan.

Jumlah aparat yang jauh lebih sedikit membuat gerbang akhirnya bobol. Massa merangsek masuk ke dalam halaman bangunan VVIP.

Kumparan, Sabtu 13 Mei 2017 - 16:05

Ratusan warga Manado, Sulawesi Utara menggeruduk Bandara Sam Ratulangi untuk menolak kedatangan Wakil Ketua DPR, Fahri Hamzah. Massa sempat melakukan pengerusakan beberapa fasilitas bandara.

Bukan hanya fasilitas bandara yang terdampak aksi penolakan warga. Sejumlah penerbangan dari Bandara Sam Ratulangi juga mengalami keterlambatan karena aksi penolakan terhadap Fahri Hamzah tersebut.

“Massa sempat masuk ke airsitenya lebih kurang lagi karena memang kita selektif, kita cegah kan nggak boleh ke sana, kemudian 20 menit bisa kita bersihkan," kata Corporate Secretary PT Angkasa Pura I, Israwadi saat dikonfirmasi, Sabtu (13/5).

Massa juga sempat masuk ke area VVIP. Fahri memang turun di area VVIP karena dia datang ke Manado untuk kunjungan kerja.

Gubernur Sulawesi Utara, Olly Dondokambey harus datang langsung ke bandara untuk menenangkan massa. Namun, beberapa massa telah melakukan pengerusakan fasilitas bandara.

“Akibat kejadian itu Angkasa Pura ada dirugikan ada kaca yang pecah dan kaca pintu kedatangan,kemudian pagar pengatur penjemputan lepas," jelasnya.

Selain fasilitas yang rusak, 4 penerbangan dari Bandara Sam Ratulangi mengalami keterlambatan. Berikut 4 penerbangan yang terdampak aksi penolakan kedatangan Fahri Hamzah:

1. JT 2743 departure Cangsha schedule 11.00 LT delay 24 menit

2. GA 684 departure Ternate schedule 11.25 LT delay 20 menit

3. Silk air 273 departure SIN schedule 13.50 LT delay 74 menit

4. IW 1182 departure Galela schedule 13.50 LT delay 79 menit

Dari kutipan beberapa media masa tersebut (perhatikan kalimat dengan huruf yang ditebalkan) dan berita-berita dari media televisi terekam fakta bahwa baik bandara yang bersetatus nasional (bandara Susilo di Kabupaten Sintang) maupun bandara yang berstatus internasional (bandara Supadio di Pontianak dan bandara Sam Ratulangi di Manado) didatangi atau diduduki oleh para demonstran. 
Diantara para demonstran tersebut ada yang membawa senjata tajam seperti parang.

Para demonstran juga melakukan perusakan fasilitas di bandara Sam Ratulangi dan bahkan mengakibatkan keterlambatan beberapa penerbangan.

Aparat keamanan (polisi) telah berusaha melakukan pencegahan, namun tidak mampu menahan para demonstran di luar area terbatas bandara sehingga mereka berhasil masuk ke apron mendekati pesawat (di Sintang dan Pontianak) dan ada yang merusak fasilitas bandara (di Manado).

ASPEK HUKUM DARI UNJUK RASA DI BANDAR UDARA

Indonesia sebagai negara anggota dari ICAO (International Civil Aviation Organization) telah meratifikasi Konvensi Chicago 1944. Dalam konvensi Chicago 1944 terdapat 19 Annex yang menjadi bagian yang tak terpisahkan dengan convensi tersebut. Salah satunya adalah Annex 17 yang mengatur masalah "Security" atau keamanan dalam penerbangan. Ketentuan-ketentuan yang ada dalam Annex tersebut belumlah menjadi peraturan yang berlaku di suatu negara sehingga menjadi peraturan perundang-undangan dan/atau peraturan lain yang berlaku di negara tersebut. Di
Indonesia salah satu peraturan yang mengatur keamanan bandara adalah Peraturan Menteri Perhubungan Nomor PM 33 Tahun 2015 Tentang "Pengendalian Jalan Masuk (Access Control) Ke Daerah Keamanan Terbatas Di Bandar Udara". Dalam PM tersebut telah ditentukan pembagian daerah-daerah di lingkungan bandar udara yaitu: 1 . Daerah Keamanan Terbatas (Security Restricted Area) adalah daerah-daerah tertentu di dalam bandar udara maupun di luar Bandar Udara yang diidentifikasi sebagai daerah beresiko tinggi untuk digunakan kepentingan Keamanan Penerbangan, penyelenggara bandar udara, dan kepentingan lain untuk digunakan kepentingan penerbangan dimana daerah tersebut dilakukan pengawasan dan untuk masuk dilakukan Pemeriksaan Keamanan.

2. Daerah Steril (Sterile Area) adalah daerah tertentu di dalam daerah keamanan terbatas (Security Restricted Area) yang merupakan daerah pergerakan penumpang sampai dengan naik ke pesawat udara dan daerah tersebut selalu dalam pengendalian dan pengawasan. 3. Daerah Terbatas (Restricted Area) adalah daerah tertentu di bandar udara dimana penumpang dan/atau non penumpang memiliki akses masuk dengan persyaratan tertentu. 4. Daerah Publik (Public Area) adalah daerah-daerah pada Bandar Udara yang terbuka untuk umum/publik. 
Daerah Keamanan Terbatas di dalam bandar udara merupakan daerah yang digunakan untuk kegiatan : a. Pergerakan pesawat udara; b. Pergerakan pegawai atau karyawan, dan peralatan kerja untuk kegiatan kepentingan penerbangan; c. Pergerakan penumpang dan bagasi yang akan naik pesawat udara; d. Pergerakan kargo dan pos yang akan dimuat ke dalam pesawat udara; dan e. Instalasi/obyek vital yang berhubungan langsung dengan pengoperasian pesawat udara. Daerahdaerah tertentu di luar bandar udara yang digunakan untuk fasilitas navigasi penerbangan, pembangkit tenaga listrik serta obyek vital lainnya dalam menunjang keselamatan penerbangan ditetapkan sebagai Daerah Keamanan Terbatas. Daerah Keamanan Terbatas tersebut harus dilindungi dengan pembatas fisik dan selalu diawasi, diperiksa pada selang waktu tertentu, dan diberi tanda peringatan (sign board) keamanan penerbangan.

Siapakah yang bertanggung jawab terhadap keamanan bandar udara ? Dalam Permenhub No.PM 31 Tahun 2013 dinyatakan bahwa Unit Penyelenggara Bandar Udara atau Badan Usaha Bandar Udara bertanggung jawab terhadap keamanan bandar udara yang dioperasikan. Selain itu dalam peraturan tersebut dinyatakan bahwa Kepolisian Republik Indonesia dan Tentara Nasional Indonesia memberikan dukungan terhadap Program
Keamanan Penerbangan Nasional sesuai dengan kebutuhan dan kondisi tingkat ancaman di bandar udara.

Ketentuan pidana bagi orang yang tanpa hak masuk ke dalam daerah tertentu di bandar udara terdapat di pasal 421 Undang-undang Nomor 1 Tahun 2009 yaitu : "Setiap orang berada di daerah tertentu di bandar udara, tanpa memperoleh izin dari otoritas bandar udara sebagaimana dimaksud dalam Pasal 210 dipidana dengan pidana penjara paling lama 1 (satu) tahun atau denda paling banyak Rp100.000.000,00 (seratus juta rupiah)."

Selanjutnya terhadap orang yang melakukan pengrusakan di lingkungan bandar udara sanksingya ada dalam Pasal 425 yang dinyatakan bahwa : "Setiap orang yang melaksanakan kegiatan di bandar udara yang tidak bertanggung jawab untuk mengganti kerugian atas setiap kerusakan pada bangunan dan/atau fasilitas bandar udara yang diakibatkan oleh kegiatannya sebagaimana dimaksud dalam Pasal 241, dipidana dengan pidana penjara paling lama 3 (tiga) tahun dan denda paling banyak Rp1.000.000.000,00 (satu miliar rupiah)."

Yang dimaksud dengan Pasal 210 adalah: "Setiap orang dilarang berada di daerah tertentu di bandar udara, membuat halangan (obstacle), dan/atau melakukan kegiatan lain di kawasan keselamatan 
operasi penerbangan yang dapat membahayakan keselamatan dan keamanan

penerbangan, kecuali memperoleh izin dari otoritas bandar udara."

Adapun ketentuan pidana bagi orang yang tanpa hak masuk ke daerah keamanan terbatas terdapat di pasal 435 yaitu : "Setiap orang yang masuk ke dalam pesawat udara, daerah

keamanan terbatas bandar udara, atau wilayah fasilitas aeronautika secara tidak sah sebagaimana dimaksud dalam Pasal 344 huruf c dipidana dengan pidana penjara paling lama

1 (satu) tahun atau denda paling banyak Rp500.000.000,00 (lima ratus juta rupiah)."

\section{ASPEK POLITIS DAN SOSIOLOGIS}

Dunia penerbangan hingga saat ini masih merupakan hal yang memiliki daya tarik dari berbagai sudut pandang. Berbagai kejadian yang menyangkut dunia penerbangan akan menjadi topik berita dan pembicaraan yang dapat berkepanjangan waktunya. Misalnya insiden dan kecelakaan pesawat udara akan menjadi berita yang lebih menarik dibandingkan peristiwa serupa yang menimpa moda transportasi lainnya. Oleh karena itu dimasa yang lalu pembajakan pesawat udara merupakan "alat" yang banyak digunakan oleh sekelompok orang untuk menarik perhatian dunia terhadap perjuangan politik mereka. Tragedi 911 terhadap menara kembar di kota New York yang sangat menghebohkan itu juga melibatkan moda transportasi udara, terlepas dari pro dan kontra terhadap latar belakang dari peristiwa tersebut, yang jelas dengan terlibatnya beberapa pesawat udara yang ditabrakkan pada bangunan tersebut menjadikan peristiwa itu menjadi lebih dramatis dan secara politis "misi" dari dalang peristiwa tersebut boleh dikatakan berhasil. Tindakan teror yang mengambil tempat di bandar udara juga banyak terjadi di beberapa belahan dunia seperti dapat kita kutip dari media sebagai berikut :

1. Peristiwa bomb bunuh diri di bandara Ataturk Istanbul Turki 28 Juni 2016.

A terrorist attack, consisting of shootings and suicide bombings, occurred on 28 June 2016 at Atatürk Airport in Istanbul, Turkey. Gunmen armed with automatic weapons and explosive belts staged a simultaneous attack at the international terminal of Terminal 2. Forty-five people were killed, in addition to the three attackers, and more than 230 people were injured. Monitoring group Turkey Blocks identified widespread internet restrictions affecting the entire country in the aftermath of the attack.

Media reports indicated that the three attackers were believed by Turkish officials to have come from Russia and Central Asia. ${ }^{[6][7][8]}$

Turkish officials said the attackers were acting on behalf of the Islamic State of 
Iraq and Levant and had come to Turkey from ISIL-controlled Syria. Commentators suggested that the attacks may have been related to stepped-up pressure against the group by Turkish authorities. No one claimed responsibility for the attack.(Wikipedia)

2. Peristiwa bomb bunuh diri di bandara Brussels dan stasiun metro di Maalbeek pada 22 Maret 2016

On the morning of 22 March 2016, three coordinated suicide bombings occurred in Belgium: two at Brussels Airport in Zaventem, and one at Maalbeek metro station in central Brussels. Thirty-two civilians and three perpetrators were killed, and more than 300 people were injured. Another bomb was found during a search of the airport. Islamic State of Iraq and the Levant (ISIL) claimed responsibility for the attacks.

The perpetrators belonged to a terrorist cell which had been involved in the November 2015 Paris attacks. The Brussels bombings happened shortly after a series of police raids targeting the group.

The bombings were the deadliest act of terrorism in Belgium's history. The Belgian government declared three days of national mourning.(Wikipedia)

\section{ANCAMAN TERHADAP}

\section{KESELAMATAN PENERBANGAN}

Bandar udara merupakan tempat yang sangat strategis dalam hal ini untuk menarik perhatian publik dengan melakukan kegiatan-kegiatan diluar fungsi dari bandar udara itu sendiri, misalnya aksi unjuk rasa, sabotase dan tindakan tindakan ekstrim lainnya. Pada sisi yang lain kegiatan dan tidakan tindakan tersebut akan dapat mengancam keamanan dan pada gilirannya akan juga mengancam keselamatan operasional penerbangan di bandar udara tersebut.

Keberadaan seseorang atau bahkan banyak orang di tempat yang tidak semestinya ada orang seperti misalnya di landasan atau taxiway sudah barang tentu akan menghambat lalu lintas penerbangan di permukaan. Demikian pula keberadaan orang atau banyak orang yang tidak berkepentingan langsung dengan operasi penerbangan di wilayah apron akan sangat riskan bagi persiapan dan penyelesaian suatu sorti penerbangan, karena di tempat itu banyak peralatan dan material yang mudah terbakar atau sensitif terhadap keberadaan benda-benda asing sisa sampah atau benda lainnya milik orang-orang tersebut yang bila tersedot mesin pesawat akan dapat merusak mesin tersebut.

Keadaan yang tidak kondusif di lingkungan suatu bandara akan berakibat pada keengganan operator atau penerbang untuk melakukan pendaratan atau tinggal landas di bandara tersebut dikarenakan resiko operasional yang tinggi bagi mereka. Dalam dunia penerbangan, sebuah bandara yang dianggap mempunyai resiko yang tinggi terhadap keamanan dan keselamatan penerbangan dikenal dengan istilah "Black Star". Sebuah bandara apabila telah diberikan predikat "Black 
Star" dari pengguna operasional penerbangan akan berdampak luas terhadap sektor-sektor lain diluar penerbangan, misalnya ekonomi, perdagangan dan pariwisata. Dengan demikian maka yang akan menanggung akibatnya adalah masyarakat di wilayah bandar udara itu berada.

Selain itu dari segi citra, apabila ada bandar udara di suatu negara yang tingkat resikonya dalam hal keamanan dan keselamatan penerbangan sangat tinggi, maka citra dari negara tersebut juga akan jatuh. Dengan citra yang buruk dari segi keamanan dan keselamatan penerbangan di suatu bandara maka secara internasional akan berdampak bagi citra negara yang bersangkutan.

\section{KESIMPULAN}

Dari uraian diatas maka kita dapat menyimpulkan bahwa:

1. Aktifitas unjuk rasa yang berlangsung di wilayah bandar udara, apalagi di daerah terbatas seperti landasan, taxiway atau apron adalah suatu tindakan yang melanggar hukum dan dapat dikenakan tindakan hukum.

2. Penggunaan wilayah bandar udara untuk kegiatan unjuk rasa atau tindakan melawan hukum linnya seperti sabotase dan sebagainya, akan dapat menjtuhkan citra dari negara dimana bandar udara itu berlokasi. Dampak dari kejadian tersebut akan sangat berarti bagi kepentingan nasional suatu negara.

3. Dunia penerbangan sangat sensitif terhadap keamanan dan keselamatan penerbangan dari suatu bandar udara, oleh karena itu jaminan atas keamanan dan keselamatan penerbangan di bandar udara menjadi prioritas negara.

4. Perlakuan penjagaan lingkungan wilayah bandar udara oleh personel Aviation Security ada baiknya untuk daerah tertentu di bantu oleh aparat TNI seperti halnya pengamanan obyek vital lainnya.

\section{DAFTAR PUSTAKA}

1. Undang-undang No.1 Tahun 2009 Tentang Penerbangan.

2. Annex 17 Chicago Convention 1944 Security

3. PerMenHub No.31 Tahun 2013 Tentang Program Keamanan Penerbangan Nasional

4. Media On Line
a. Tempo.co
b. PKSPuyengan.com
c. Kompas.com
d. Liputan6.com
e. Kumparan
f. Wikipedia 